IRSTI 14.23.05

\author{
${ }^{1}$ Mukasheva A.B., ${ }^{2}$ Korchakina T.A. \\ ${ }^{1}$ Doctor of Pedagogical Sciences, Acting Professor, \\ Al-Farabi Kazakh National University, Kazakhstan, Almaty, e-mail: seko2000@mail.ru \\ ${ }^{2}$ M.A. Student, Al-Farabi Kazakh National University, Kazakhstan, Almaty, \\ e-mail: taiseikhel@mail.ru
}

\title{
HIGH SCHOOL STUDENTS' REPRODUCTIVE HEALTH PROTECTION AS ONE OF THE MOST IMPORTANT SOCIAL AND PEDAGOGICAL ACTIVITY ASPECTS
}

Reproductive health is the guarantor of a successful future for the country, which is why it is recommended to pay special attention to its protection and strengthening. The high incidence of early sexual intercourse, STIs, teenage pregnancies and abandonment of their own newborns, a positive attitude of adolescents to premarital sexual relations, early marriages, abortions and miscarriages, using alcohol and tobacco, lack of awareness or misinformation about sexual behavior, lack of sex education due to the high interest in the study of this problem. The article raises the actual topic of high school girls' reproductive health. There are statistic data that indicate the reproductive health deterioration tendency. For the scientific and pedagogical study of this problem, diagnostic work was conducted among 56 female high school students with the help of a selfdeveloped questionnaire. At this stage, the extent of their lack of awareness in this area was clarified, as well as a rather frivolous attitude to their own reproductive health and behavior. After the survey stage, we carried out educational work, including a lecture, viewing a documentary film and conducting a discussion to form more attentive attitude to their reproductive health and sexual behavior.

Key words: reproductive health, adolescents, sex education.

\author{
${ }^{1}$ Мукашева А.Б., ${ }^{2}$ Корчакина Т.А. \\ 1педагогика ғылымдарының докторы, профессор м.а \\ әл-Фараби атындағы Қазақ ұлттық университеті, Қазақстан, Алматы қ., e-mail: seko2000@mail.ru \\ ${ }^{2}$ магистрант, әл-Фараби атындағы Қазақ ұлттық университеті, Қазақстан, Алматы қ., e-mail: taiseikhel@mail.ru
}

Жоғары сынып оқушыларының репродуктивті денсаулығын қорғау әлеуметтік-педагогикамық қызметтің маңызды аспектілерінің бірі ретінде

Репродуктивті денсаулық елдің табысты болашағының кепілі болып табылады, сондықтан оны қорғау мен нығайтуға ерекше назар аудару ұсынылады. Ерте жыныстық байланыстардың, ЖЖБИ, жасөспірім жүктіліктерінің таралуының және жаңа туған нәрестелерден бас тартуының жоғары дәрежесі, жасөспірімдердің мейірімді жыныстық байланыстарға деген оң көзқарасы, ерте некелер, түсік тастау, алкоголь мен темекіні пайдалану, сондай-ақ жыныстық мінезқұлық туралы хабардар болмауы немесе Аезинформация, жыныстық тәрбиенің тиісті деңгейде болмауы осы проблеманы зерттеуге жоғары қызығушылық тудырады. Мақалада жоғары сынып қыздарының репродуктивті денсаулығын қорғаудың өзекті тақырыбы көтеріледі. Репродуктивті денсаулықтың нашарлау үрдісінің бар екенін көрсететін статистикалық, деректер келтірілген. Осы проблеманы ғылыми-педагогикалық зерттеу үшін 56 жоғары сынып қыздарының арасында өзбетінше әзірлеген сауалнаманың көмегімен диагностикалық жұмыс жүргізілді. Осы кезеңде олардың осы салада хабардар етпеу дәрежесі, сондай-ақ өзінің репродуктивті денсаулығы мен мінез-құлқына өте жеңіл мағыналы көзқарас анықталды. Сауалнама кезеңінен кейін өз репроАүктивті денсаулығы мен жыныстық мінез-құлқына мұқият қарауды қалыптастыру мақсатында дәрісті, деректі фильмді қарау мен талқылауды және пікірталасты қамтитын тәрбие жұмысы жүргізілАі.

Түйін сөздер: репродуктивті денсаулық, жасөспірімдер, жыныстық тәрбие. 
Mukasheva A.B., Korchakina T.A.

\author{
${ }^{1}$ Мукашева А.Б., ${ }^{2}$ Корчакина Т.А. \\ 'Аоктор пеАагогических наук, и.о. профессора, Казахский национальный университет имени аль-Фараби, \\ Казахстан, г. Алматы, e-mail: seko2000@mail.ru \\ ${ }^{2}$ магистрант, Казахский национальный университет имени аль-Фараби, \\ Казахстан, г. Алматы, e-mail: taiseikhel@mail.ru
}

\title{
Охрана репродуктивного здоровья старшеклассниц как один из важнейших аспектов социально-педагогической деятельности
}

\begin{abstract}
Репродуктивное здоровье является гарантом успешного будущего страны, поэтому его охране и укреплению уделяется особое внимание. Высокая степень распространения ранних половых связей, рост подростковых беременностей и отказов от новорожденных, положительное отношение подростков к добрачным половым связям, ранние браки, аборты и выкидыши, употребление алкоголя и табака - современные проблемы общества. Они связаны с неинформированностью или дезинформацией о половом поведении, отсутствием полового воспитания на должном уровне, что актуализирует рассмотрение и изучение данной проблемы. В статье поднимается актуальная тема охраны репродуктивного здоровья девушек-старшеклассниц. Приведены статистические данные, которые свидетельствуют о наличии тенденции ухудшения репродуктивного зАоровья. Аля научно-педагогического исследования данной проблемы была проведена Аиагностическая работа среди 56 девушек-старшеклассниц с помощью разработанной авторами анкеты. На Аанном этапе была выяснена степень неинформированности школьниц в этой области, а также Аостаточно беспечное отношение к собственному репродуктивному зАоровью и поведению. После анкетирования с группами старшеклассниц была проведена воспитательная работа, включающая в себя лекцию-беседу, просмотр и обсуждение документального фильма, Аискуссию с целью формирования более внимательного отношения к своему репродуктивному зАоровью и половому поведению.
\end{abstract}

КАючевые слова: репродуктивное здоровье, подростки, половое воспитание.

\section{Introduction}

Protection and strengthening of reproductive health implementation, ensuring high-quality sexual education of younger generation has to become one of paramount tasks in an educational system as the destructive sexual behavior and low level of reproductive health represent not only an individual problem, concerning intimate parties of the personality, but also social, influencing ideas about family institution and marriage importance, reproduction of healthy posterity and other important aspects of modern society.

Activities for protection and the analysis of younger generation reproductive health and behavior is necessary because of their acceleration which was recorded at the beginning of the XX century and proceeds now. Harmful influence of this trend is observed that there is an essential gap between the puberty period and social and psychological maturity offensive of the teenager that entails serious problems formation in further socialization.

The UNFPA representatives focus attention that insufficient level of informing younger generation on sexual behavior, the lack of preventive measures, and inaccessibility of service in the reproductive health field lead to formation of problems in the period of teenage age which are fraught with irreversible consequences in the future.
However, to bring up questions of sexual and reproductive health, to lead preventive discussions and informative and educational actions in an education system at the schools still is considered shameful and responsibility is transferred to the parents and close relatives. But whether parents are ready to discuss openly such subjects with children and to provide them reliable information? During Turdaliyeva B.S., Aimbetova G.E. and Musayeva B.A. sociological poll it is established that more than $80 \%$ of the interviewed parents of 998 pupils of 7-11 classes never talked to them about sex or did it occasionally. Among pupils there are $67 \%$ of girls and $77 \%$ of boys never started conversations of such character with parents. Only $40.7 \%$ of the pupils participating in poll are informed on existence of the Health youth centers. Such data directly confirm the low level of younger generation knowledge of sexual behavior which is vital for protection and maintenance of their reproductive health up to standard (Turdaliyeva, 2010: 53).

In this regard young people are forced to look for missing information floating around the Internet where quite often it is distorted or absent at all. As a result they gain the fragmented and doubtful knowledge which can entails big psychological, physiological and social problems. Teenagers get to a vicious circle and quite often they should gain necessary knowledge by trial 
and error on their own experience at the risk of their own health.

Not so long ago, the independent researcher and the activist Karlygash Kabatova was created the online platform on sexual education for youth "UyatEmes.kz" with the purpose to avoid such consequences, where the team of professional psychologists and medical workers answer questions and give exhaustive and reliable information about sexual and reproductive health, features of intersexual communication, ways of protection against sexual harassments etc.

Modern researches show that the world practice of introduction of sexual education in school education, yields the positive results: the number of pregnancies and abortions among teenagers decreases, cases of incidence of STD and HIV decrease, the children having basic knowledge of sexuality of the person suffer from pedophiles less often, than their peers who were less grounded in this question. Besides, sex education promotes formation of the strong interpersonal relations and strengthening of consciousness of the person (Nureyeva, 2000: 119).

There is also an opposite opinion of youth morality observers. We can often hear from them that sex education promotes liberation of teenagers. In our opinion, on the contrary, sexual education promotes formation of a competent and responsible attitude to own reproductive health and increase responsibility level in sexual behavior.

The purpose of our research was clarification of high school girl students' reproductive behavior features and increases their knowledge level in this area.

\section{Materials and methods}

If to look at development of introduction of sexual education in an educational system in a historical context of the Kazakhstan society, it is possible to see that this issue was practically not discussed on a national level, did not rise as one of sharp in an education system and had a resistant trend of concealment in society. If in the Soviet period there were attempts of judgment and studying of the matter, they also quickly fell, as well as arose. It was connected first of all with the fact that teaching such courses as "Ethics and psychology of family life", "Bases of the Soviet family and family education", "Hygienic and sex education", elective courses on marriage, love, intersexual communication and reproductive health most often laid down on shoulders of unprepared teachers which were in great need the help of experts when holding such occupations with pupils. Therefore in the 1980th years carrying out similar school courses was cancelled finally (Karam, 2012: 113).

There were applied the research methods of the historical analysis of development of a problem, an interview method, poll method, questioning, verbal and visual teaching methods.

Using self-developed questionnaire by us there were interviewed 56 schoolgirls of 1011 classes of public institution "High school of V.G. Belinsky with the preschool mini-center". Our questionnaire comprised 14 questions of reproductive health and factors negatively on it influencing. After a diagnostic investigation phase, we gave a lecture with conversation elements about a concept of reproductive health, factors negative on it influencing and measures of their prevention. There were distributed informative booklets to girls about reproductive health of youth and STD. Besides, there were watched and discussed a series of documentaries about influence of alcohol on birth rate and newborns health.

\section{Literature review}

The period of the 1990th years became a key stage in development of the matter. There was signed The United Nations Convention of the child rights and accepted the strategy "Kazakhstan 2030". In strategy "Kazakhstan — 2030", among the important priority directions the attention is focused on issues of alcoholism, drug addiction and smoking harmful influence on the nation health, improvement of women and children health, younger generation of the country, problems of planning of family, abortions, the general moral shape of the nation against the background of preservation and education of traditional values (Nazarbayev, 1997).

In 2001 it was marked by release of the Concept on moral sex education in the Republic of Kazakhstan. After the carried-out analysis of the sexual relations, there were entered sharply concerning society and the state following problems: lack of knowledge of strengthening and maintaining reproductive health, lack of ability of adult population to render the qualified help to younger generation in questions of sexual behavior, increase in STD, growth of teenage pregnancies, immoral sexual behavior. This Concept regulated carrying out effective policy in the sphere of reproductive health of children, teenagers and youth in general, offered new approaches to the organization of moral and sexual education taking into account process of rapid acceleration and involvement in process of all interested structures of society and the state (the Government of RK, 2001). 
In 2004 the Law of RK "About the Reproductive Rights of Citizens and Guarantees of Their Implementation" was entered. This law regulated important questions concerning reproductive health and provided the rights of minors for "reproductive health protection and also moral sex education and education". However, in 2009 the law became invalid, and since then was not replaced with anything (the Law RK, 2004).

In 2010 the state program of health development care of RK of "Salauatta Kazakhstan" of 2011-2015 was approved. Problems of reproductive health and spread of STD were accurately reflected in this program. The reason determined unsafe sexual behavior of the population, mainly, of youth. As the solution of these problems prevention of smoking, the use of drugs and alcohol, need of maintaining ZOZH and training of social psychologists at schools were offered. But, nothing was told about instilling in teenagers of that safe sexual behavior which lack was the main reason for problems of reproductive health and destructive sexual behavior of youth (Nazarbayev, 2010).

In 2013 in the public youth policy concept of the Republic of Kazakhstan till 2020 concerning youth reproductive health only one point saying about study of creation possibility and ensuring access of youth to the uniform information database on questions of reproductive health protection is considered. It is absolutely unclear who and how implemented this point, though an idea is very good which unfortunately was not realized (the Government of RK, 2013).

In 2016 in the family and gender policy concept in the Republic of Kazakhstan till 2030 problems of teenage pregnancy, abortions and early marriages, as a result of ignorance of the younger generation in sexual sex issues were openly recognized. This document can become the main milestone in development of the solution of problems of sexual education in the Republic of Kazakhstan as it is offered as the main tool of their decision: "extension of programs of teenagers training and youth to questions of sexual and reproductive health protection, safe sexual behavior, prevention of undesirable pregnancies, prevention of transfer of STD/HIV" in the system of an average and vocational training (Nazarbayev, 2016).

As well as this Concept program documents in the majority bore declarative character and did not find a response neither among public authorities, nor in wide society. The problem does not find due consideration to itself to this day, continues to be suppressed under cover of maintaining morality by silence on shameful subjects. And the facts speak about need to carry on an open conversation on sexual education.

In 2012 the UN Fund in the field of the population (YuNPFA) conducted a national research. By results of which it became clear that $64.4 \%$ of the interviewed from 15 to 19 years came into sexual contact being school students. And $13.6 \%$ got the first sexual experience up to 15 years. According to experts annually there are 7000 pregnancies at girls to full age (Tanirbergenov, 2014: 54).

And meanwhile, in television news plots and the Internet space we even more often see confirmation of polls and YuNPFA experts opinion as publicizing by journalists of the teenage pregnancy facts, abortions, newborns refusal or egregious cases of babies emission in refuse and trash cans with the purpose to hide teenagers the immoral sexual behavior.

This problem is terrible not only from social, but also from the medical point of view. Early sex life of teenagers, pregnancy and childbirth at so early age render irreversible consequences on a weak girl's organism. They are meant as STD, patrimonial injuries, infertility, a high mortality rate of newborn and young mothers. After obtaining the status of parents, teenagers are most often forced to give up education and looking for ways of material security. The situation becomes complicated if the child's father the minor too, and the family refuses to give the help and support to young parents (Turdaliyeva, 2014: 17).

In a consequence it turns out that such girls and guys lacked sexual literacy, courage to ask in time for the help or information parents or competent experts, material resources for acquisition of various contraceptives or sufficient level of morality in questions of sexual behavior. Young mothers in society most often are exposed to condemnation, rejection, they are rejected by families and friends under fear to be held up to shame. But in our opinion, it is better to prevent and warn than then to solve problems of young mothers and the thrown newborns. Society has to unite not for this purpose in large quantities to condemn and to avoid similar cases and problems in the field of youth sexual behavior by means of younger generation highquality sexual education organization.

As a result of Almaty and Karaganda student's poll which is carried out by independent researchers and public activists Kabatova K. and Marinin S. at schools answered a question of sexual education need: "No, it does not suit our mentality", "Our parents somehow coped, and the modern youth 
will be able", "School students find all necessary information in the Internet". However, authors absolutely reasonably do not agree with such answers and in the research conducted with financial and consulting support Soros Kazakhstan Fund, at first, in detail consider historical stages of youth sexual education introduction in Kazakhstan. Secondly, give the following reasons for ignoring of introduction of sexual education possibility in Kazakhstan:

- secret ban of discussion of sexual and youth reproductive health subject;

- a lack of political will and lack of system approach for the youth sexual and reproductive health problems solution;

- insufficient interdepartmental interaction concerning sexual education and also rearrangement of responsibility on the international and domestic nongovernmental organizations;

- focus of an educational system on providing the academic knowledge, but not social skills;

- one-sided and formal realization of reproductive health initiatives.

Thirdly, there offered 3 options of public policy for the problems solution connected with reproductive health of teenagers. And fourthly, provide the concrete recommendations to government departments, media community and also civil society and activists. All these projects are aimed at the address of public attention and the persons responsible for decision-making in the sphere of public policy for need of younger generation ensuring access of the Republic of Kazakhstan to high-quality education for questions of sexual and reproductive health protection and personality free from gender prejudices formation (Kabatova, 2018: 19).

We, as well as the above-stated authors see a solution, first, in its recognition and secondly, in introduction of high-quality informing teenagers concerning sexual and reproductive health through the obligatory system of an average and a secondary special education.

Estonia which was also a part of the USSR has positive experience of such method of the solution of problems of reproductive health of teenagers. In 1996 the subject "Studying of the Person and Society" within which paid special attention to sexual education and education was entered into the training program. Level of abortions to the country among teenagers of $15-19$ years decreased by $61 \%$. The annual indicator of cases of infection of HIV in 8 years decreased from 560 to 25, and syphilis from 116 in 1998 up to 2 in 2009, incidence of gonorrhea
- from 263 cases in 1998 up to 20 in 2009. Except introduction of an obligatory subject to the school program in Estonia created the centers of friendly youth. Such complex and competently undertaken reform of sexual education also led to successful decrease in indicators of teenage pregnancy, abortions and infections of STD (Haldre, 2012: 351).

And in Germany already at elementary school pupils gain knowledge of gender distinctions, of process of conception, pregnancy and childbirth, of physiological and psychological changes of an organism during the pubertal period. In middle and high school special attention is paid to ethics of intersexual communication, to legal and social bases of family life sexual education received the Obligatory status in the system of school education as early as here in the 1990s. At the moment the culture of children and teenagers in questions of sexual and reproductive health, early experience of sex life and possession of knowledge of contraception, at the same time a share of teenage pregnancies and abortions one of low in Europe is result of such policy of sex education (Wegner, 2016: 83).

Thus, in our opinion, further ignoring of the problems connected with reproductive health of teenagers and an obligatory course of sexual education in the school program will lead lack of an open discussion on a national level only to deterioration in current situation. If we want boomerang effect, then it is worth paying attention to positive experience of foreign countries and to remember that that at the moment when the person leaves limits of school, chances to receive the structured and reliable, scientific verified knowledge of the sexual relations considerably decreases (Ponzetti, 2016: 27).

\section{Results and discussion}

There was carried out diagnostic work among 56 high school girl students with the help independently self-developed questionnaires by us for a scientific and pedagogical research of this problem. The research was conducted on the basis of KGU "high school of V.G. Belinsky with DMTs". 56 senior students participated in questioning: 27 schoolgirls of the 10th classes and 29 schoolgirls of the 11th classes. The purpose of questioning was definition of girls' knowledge degree about reproductive health and the factors having negative effect on it and also studying of modern features of reproductive behavior of young girls. The questionnaire contains 14 closed questions. 
Following the results of questioning high degree of not knowledge of girls of reproductive health and also quite flippant attitude own reproductive health and behavior was established. Only $48 \%$ of respondents precisely know that such reproductive health. During the information lecture after the poll the value of this term was in detail explained to girls and detailed interpretation of this term from WHO is given. Reproductive behavior questions knowledge of the girl is gained most often from peers and the senior companions (fig. 1). The fact that none of respondents noted that he gains knowledge from health workers or teachers guards. From this it is possible to draw a conclusion that information obtained by them cannot be reliable. For elimination of this problem we provided the list the Internet of the websites on which experts, but not users of forums online can provide to girls the qualified help.

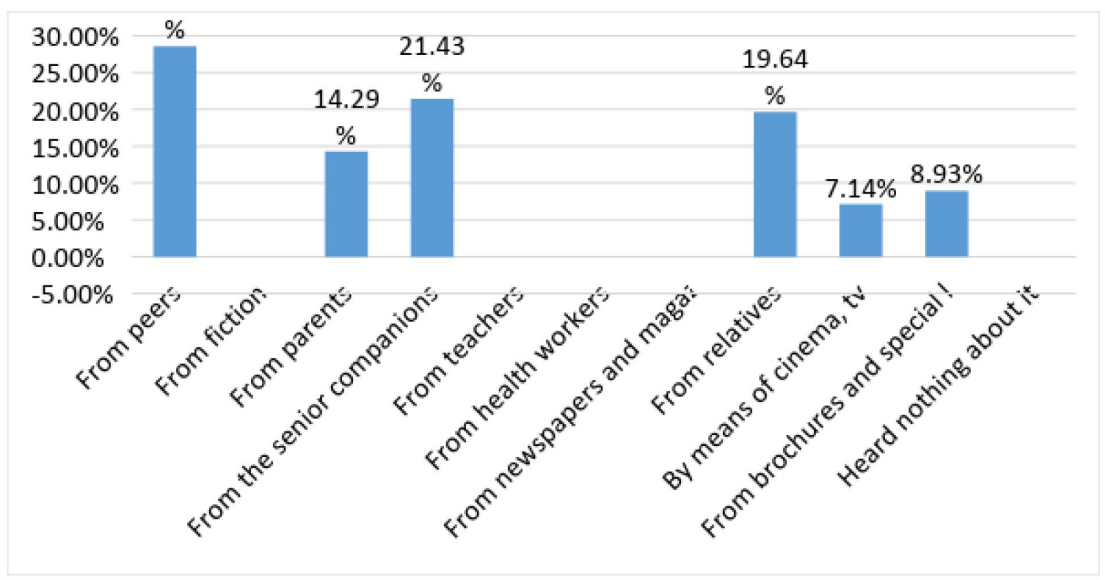

Figure 1 - Where do you receive reproductive health data from?

$76.79 \%$ of respondents note that parents never spoke with them about reproductive health, STD, pregnancy and sexual contacts. Nevertheless, $57.14 \%$ of respondents know that such STD. $85.71 \%$ know about abortion consequences, but $66.07 \%$ allow abortion under certain circumstances.
Whether on a questionnaire question "Do you take alcoholic drinks?" $83.93 \%$ answered "No", and $16.07 \%$ of girls answered that they take alcoholic drinks, from them $8.93 \%$ on holidays, $1.79 \%$ of times a month and $5.36 \%$ more often than time in a month (fig. 2).

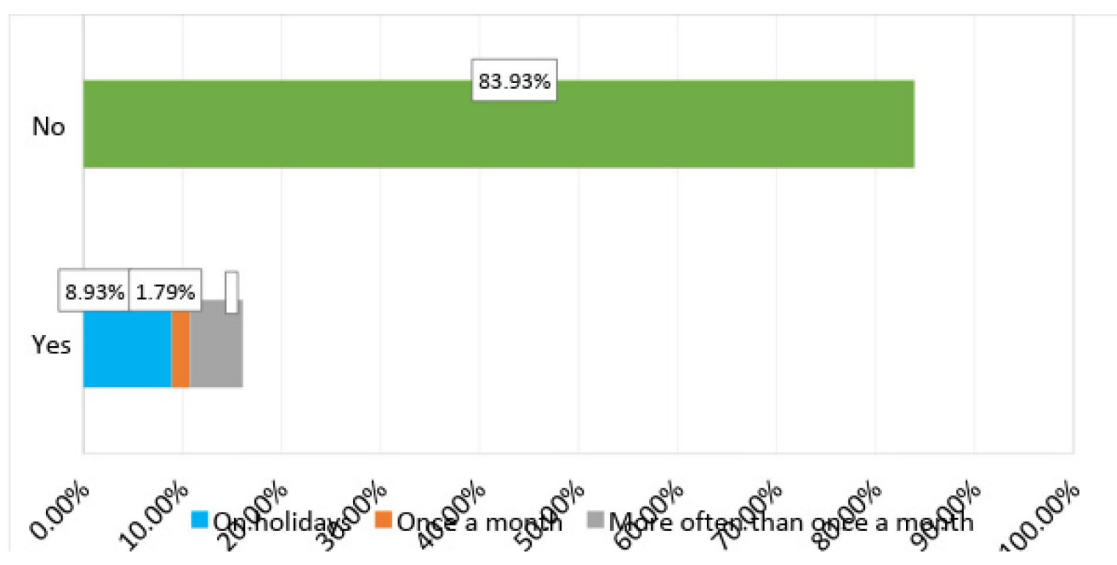

Figure 2 - Whether do you take alcoholic drinks? If «Yes», then how often?

About harm of alcohol, tobacco and drugs on reproductive health there is a set documentary and educational films and articles. One of such movies about influence of alcohol on birth rate and health 
of newborns was watched after obtaining results of questioning. We hope that it will make the correct impression which will provide refusal of consumption of alcoholic beverages on girls.

Only $37.50 \%$ of the interviewed girls consider inadmissible the sexual relations to marriage. $62.5 \%$ of respondents allow sexual communications before marriage. From them $14.29 \%$ find possible it from 16 years, $23.21 \%$ from 18 years and $25.00 \%$ consider admissible the sexual relations before marriage if the age exceeds a mark of majority (fig. 3).

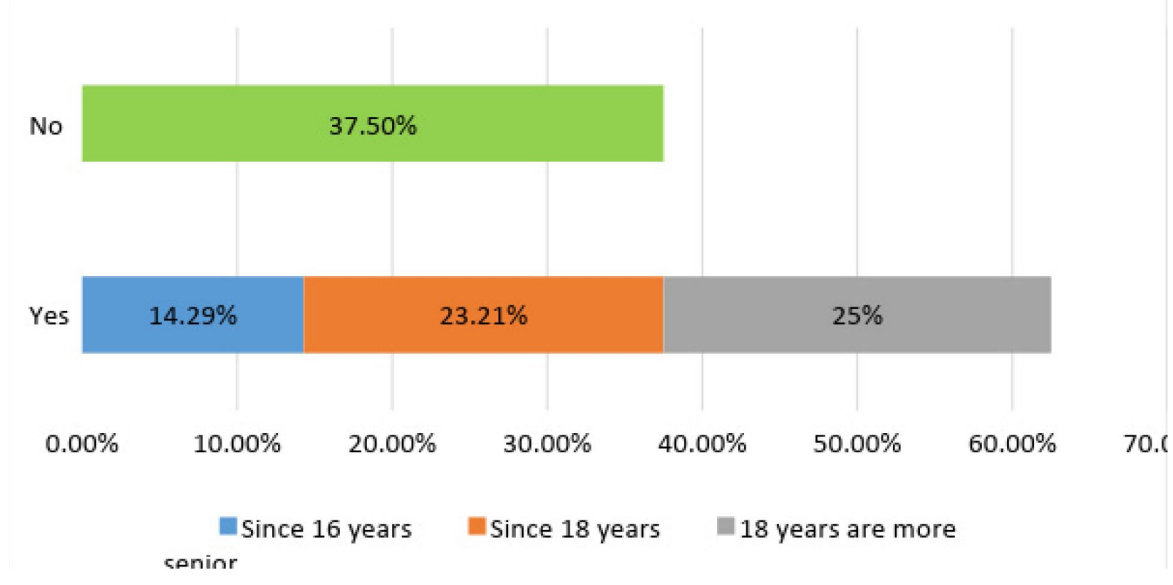

Figure 3 - Whether you allow the sexual relations before marriage? If «Yes», then from what age?

$57.14 \%$ of respondents consider that the child has to be given birth in marriage, $14.29 \%$ find it difficult to answer in this respect and $28.57 \%$ do not consider that the child has to be surely born in marriage (fig. 4).

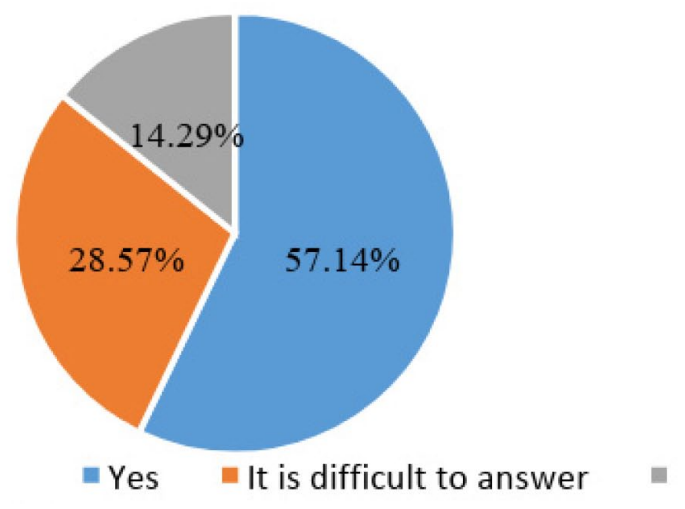

Figure 4 - Whether you consider that the child has to be given birth in marriage?

From 56 interviewed girls of $83.93 \%$ never addressed for consultation on reproductive health, most of them-27.66\% hesitated, and $23.4 \%$ did not know where to ask such questions (fig. 5). 


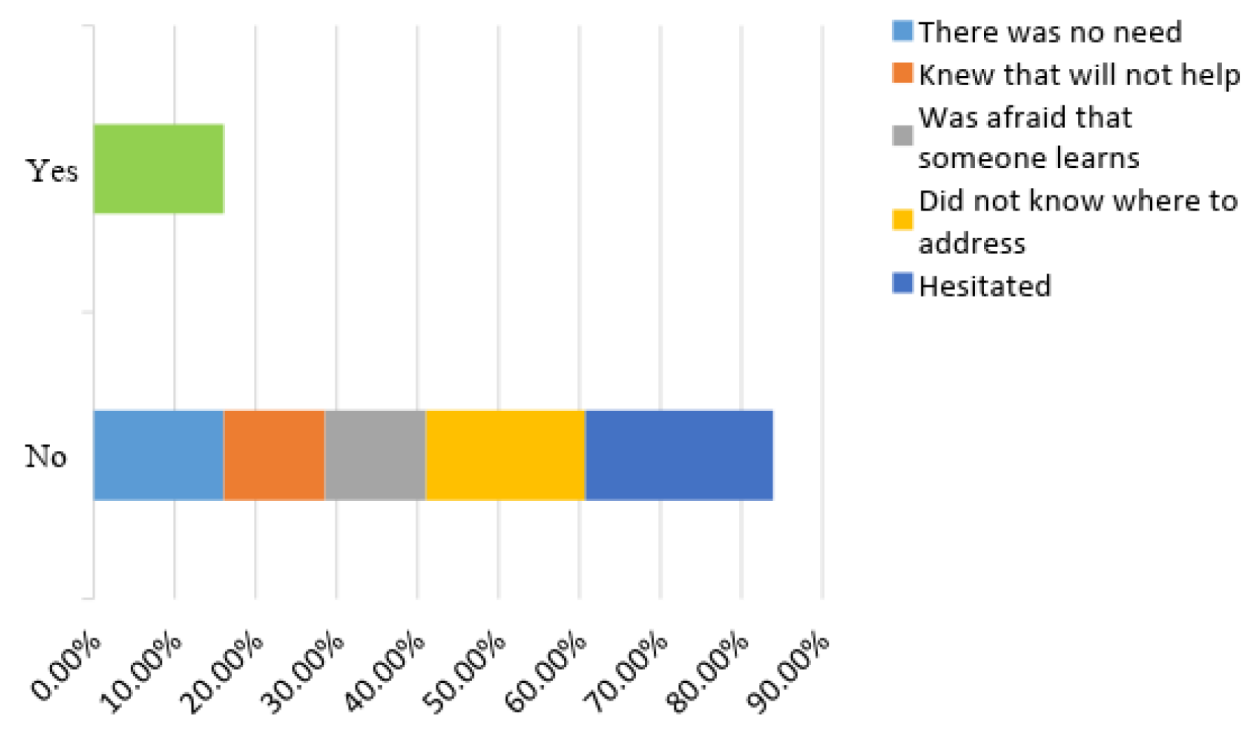

Figure 5 - Whether you had to ask for the help, consultation on the problems connected with the sexual relations? If «No», then why?

Girls who asked on such questions for the help looked for answers to the questions at Internet forums that is extremely subjective and doubtful sources of information such.

After a stage of questioning we carried out the informative and educational work including a lecture, viewing and discussion of documentaries and a discussion for the purpose of formation of more attentive attitude towards the reproductive health and sexual behavior. Besides, booklets with medical information on features of reproductive health and STD were provided to girls. Also, we provided information about reliable the Internet the websites, such as "UyatEmes.kz.", where they can receive answers to the questions interesting them from experts and read competent information on the reproductive system of the person, bases of intersexual communication, contraception, STD and many other aspects of sexual behavior which concern them.

\section{Conclusion}

All these data allow drawing a conclusion on insufficient knowledge of young girls' reproductive health, lack of rendering the qualified help and support from medical workers and educational institution teachers to them. Girls obtain so important information from peers, the senior girlfriends and prefer to address for answers to Internet forums. Besides, ambiguous views of sexual behavior aspects, assumption of a possibility of premarital sexual communications, the births of children out of marriage and a possibility of interruption of the first pregnancy are observed. Very few parents conduct educational conversations about sex education and reproductive health. In our opinion, the received results demonstrate urgent need of holding information conversations on protection of reproductive health and formation of responsible sexual behavior.

It is always easier to prevent a problem, than to solve its irreversible detrimental consequences affecting health of younger generation and all spheres of public life so and on the future of the whole country. For this reason, in educational institutions it is necessary to approach the solution of the matter systemically, with involvement of the medical sphere experts, parents, subject teachers, school psychologists, social teachers and activists from public organizations.

\section{References}

1 Турдалиева Б.С., Аимбетова Г.Е., Мусаева Б.А. Особенности полового воспитания и его влияние на формирование здоровья подростков // Вестник КазНМУ. Материалы III Международной научно-практической конференции «Актуальные вопросы предупреждения распространения табачной эпидемии». 2010. - С. 53.

2 Нуриева, Н. С. Нравственно-половое воспитание подростков в школах США :дис. . канд. Пед. наук : 13.00 .01 / Н. С. Нуриева. - Казань, 2000. - 227 с. 
High School Students' Reproductive Health Protection as one of the Most Important Social and Pedagogical Activity Aspects

3 Карам А. О. Сексуальное воспитание подростков и проблемы полового просвещения // Известия АГУ. - №2-1(74), 2012 г. $-208 \mathrm{c}$.

4 Послание Президента страны народу Казахстана 1997 года, «Казахстан — 2030: Процветание, безопасность и улучшение благосостояния всех казахстанцев». Просмотрено 15 ноября 2018 // http://adilet.zan.kz/rus/docs/K970002030_.

5 Постановление Правительства Республики Казахстан от 21 ноября 2001 года №1500 «О Концепции по нравственно-половому воспитанию в Республике Казахстан». Просмотрено 19 ноября 2018 г. // http://prikaz.kz/ru/50127-O-Kontseptsiipo-nravstvennopolovomu-vospitaniyu-v.html

6 О репродуктивных правах граждан и гарантиях их осуществления: Закон РК от 16 июня 2004 года. Просмотрено 20 ноября 2018 г. // http://adilet.zan.kz/rus/docs/Z040000565

7 Об утверждении Государственной программы развития здравоохранения Республики Казахстан «СаламаттыҚазақстан» на 2011- 2015 годы: Указ Президента Республики Казахстан. - Астана, 29 ноября 2010 г. Просмотрено 20 ноября 2018 г. // http://adilet.zan.kz/rus/docs/U1000001113

8 О Концепции государственной и молодежной политики Республики Казахстан до 2020 года «Казахстан 2020: путь в будущее»: Постановление Правительства Республики Казахстан от 27 февраля 2013 года №191. Просмотрено 21 ноября 2018 г. // http://adilet.zan.kz/rus/docs/P1300000191

9 Об утверждении Концепции семейной и гендерной политики в Республике Казахстан до 2030 года: Указ Президента Республики Казахстан от 6 декабря 2016 года №384. Просмотрено 21 ноября 2018 г. // http://adilet.zan.kz/rus/docs/ U1600000384

10 Танирбергенов С., Абуова Г. Ситуационный анализ: Репродуктивное здоровье населения Казахстана (2008-2014), ЮНФПА. - С. 54.

11 Турдалиева Б.С., Аимбетова Г.Е., Рамазанова М.А., Алтынбекова У.А., Досмаилова И. Проблема ранней беременности и абортов среди подростков и молодежи // Вестник КазНМУ. - 2014.- №2(4)

12 Кабатова К., Маринин С. Учить или молчать? Половое просвещение в РК. 2018г. - 29с. [Электронный ресурс]: https://www.soros.kz/ru/research_about_sexual_education/

13 Haldre, Kai et al.,»Youth sexual health improvement in Estonia, 1990 - 2009: The role of sexuality education and youthfriendly services» // The European Journal of Contraception and Reproductive Health Care, October 2012; 17: 351-362, P. 351.

14 Wegner, C., Seide, C., Zehne, C. Sexuality Education in Germany: Example of a Comprehensive, Learner-Centered Teaching Unit // Education and Health. - 2016. - Vol. 34(3). - Pp. 79-83.

15 Ponzetti, James J. Jr., et al. "Evidence-based Approaches to Sexuality Education: A Global Perspective" New York: Routledge, 2016. P. 27.

\section{References}

1 Turdalieva B.S., Aimbetova G.E., Musaeva B.A. (2010) Osobennosti polovogo vospitaniya i ego vliyanie na formirovanie zdorov'ya podrostkov [Features of sex education and its influence on formation of health of teenagers]. Almaty, Messenger of KAZNMU, Materials III of the International scientific and practical conference «Topical Issues of Prevention of Distribution of Tobacco Epidemic», p. 53. (In Russian).

2 Nurieva, N. S. (2000) Nravstvenno-polovoe vospitanie podrostkov v shkolah USA [Moral sex education of teenagers at schools of the USA].- Kazan', 2000. - p. 227. (In Russian).

3 Karam A. O. (2012) Seksual'noe vospitanie podrostkov i problem polovogo prosveshcheniya [Sexual education of teenagers and problem of sexual education]. IzvestiyaAGU. - №2-1(74), - p. 208. (In Russian)

4 Poslanie Prezidenta strany narodu Kazahstana 1997 goda, «Kazahstan — 2030: Procvetanie, bezopasnost’ iuluchshenie blagosostoyaniya vsekh kazahstancev». Prosmotreno 15 noyabrya 2018 // http://adilet.zan.kz/rus/docs/K970002030_.(In Russian)

5 Postanovlenie Pravitel'stva Respubliki Kazahstanot 21 noyabrya 2001 goda №1500 «O Koncepcii po nravstvenno-polovomu vospitaniyu v Respublike Kazahstan». Prosmotreno 19 noyabrya 2018 g. // http://prikaz.kz/ru/50127-O-Kontseptsii-ponravstvennopolovomu-vospitaniyu-v.html (In Russian).

6 O reproduktivnyh pravah grazhdan i garantiyah ih osushchestvleniya: Zakon RK ot 16 iyunya 2004 goda. Prosmotreno 20 noyabrya 2018 g. // http://adilet.zan.kz/rus/docs/Z040000565 (In Russian).

7 Ob utverzhdenii Gosudarstvennoj programmy razvitiya zdravoohraneniya Respubliki Kazahstan «SalamattyҚаzaқstan» na 2011- 2015 gody: Ukaz Prezidenta Respubliki Kazahstan. - Astana, 29 noyabrya 2010 g. Prosmotreno 20 noyabrya 2018 g. // http:// adilet.zan.kz/rus/docs/U1000001113 (In Russian).

8 O Koncepcii gosudarstvennoj i molodezhnoj politiki Respubliki Kazahstan do 2020 goda "Kazahstan 2020: put' v budushchee”: Postanovlenie Pravitel'stva Respubliki Kazahstan ot 27 fevralya 2013 goda №191. Prosmotreno 21 noyabrya 2018 g. // http:// adilet.zan.kz/rus/docs/P1300000191 (In Russian).

9 Ob utverzhdenii Koncepcii semejnoj i gendernoj politiki v Respublike Kazahstan do 2030 goda: Ukaz Prezidenta Respubliki Kazahstan ot 6 dekabrya 2016 goda №384. Prosmotreno 21 noyabrya 2018 g. // http://adilet.zan.kz/rus/docs/U1600000384 (In Russian).

10 Tanirbergenov S., Abuova G. (2014) Situacionnyj analiz: Reproduktivnoe zdorov'e naseleniya Kazahstana [Situation analysis: Reproductive health of the population of Kazakhstan] UNFPA. - p. 54. (In Russian).

11 Turdalieva B.S., Aimbetova G.E., Ramazanova M.A., Altynbekova U.A., Dosmailova I. (2014) Problema rannej beremennosti i abortov sredi podrostkov i molodezhi [Problem of early pregnancy and abortions among teenagers and youth] Vestnik KazNMU. - 2014.- №2(4). (In Russian). 
12 Kabatova K., Marinin S. (2018) Uchit' ili molchat'? Polovoe prosveshchenie v RK [To learn or be silent? Sexual education in RK] https://www.soros.kz/ru/research_about_sexual_education/, p.29 (In Russian).

13 Haldre, Kai et al. (2012) Youth sexual health improvement in Estonia, 1990 - 2009: The role of sexuality education and youth-friendly services. The European Journal of Contraception and Reproductive Health Care. 17: 351-362, P. 351.

14 Wegner, C., Seide, C., Zehne, C. (2016) Sexuality Education in Germany: Example of a Comprehensive, Learner-Centered Teaching Unit // Education and Health. 34(3). - Pp. 79-83.

15 Ponzetti, James J. Jr., et al. (2016) Evidence-based Approaches to Sexuality Education: A Global Perspective. New York: Routledge, 2016. P. 27. 